\title{
Space-use patterns of Malay civets (Viverra tangalunga) persisting within a landscape fragmented by oil palm plantations
}

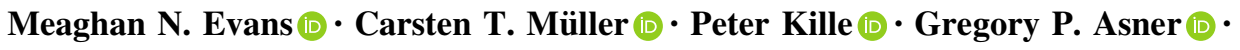 \\ Sergio Guerrero-Sanchez $(\mathbb{1} \cdot$ Mohd Soffian Abu Bakar • Benoit Goossens (i)
}

Received: 24 June 2020/ Accepted: 26 December 2020/Published online: 16 January 2021

(C) The Author(s) 2021

\begin{abstract}
Context Agricultural land use is expanding and is a major driver of the biodiversity crisis. Land use planning initiatives seeking to optimize wildlife conservation are hindered by a lack of baseline data quantifying species' tolerance to human-modified landscapes.
\end{abstract}

Supplementary Information The online version of this article (https://doi.org/10.1007/s10980-020-01187-2) contains supplementary material, which is available to authorized users.

M. N. Evans $(\bowtie) \cdot$ S. Guerrero-Sanchez $\cdot$ B. Goossens Danau Girang Field Centre, Wisma Muis, Block B, 5th Floor, 88100 Kota Kinabalu, Sabah, Malaysia

e-mail: evansmn24@gmail.com

M. N. Evans - C. T. Müller · P. Kille

S. Guerrero-Sanchez · B. Goossens $(\bowtie)$

School of Biosciences, Cardiff University,

Cardiff CF10 3AX, UK

e-mail: goossensbr@cardiff.ac.uk

\section{G. P. Asner}

Center for Global Discovery and Conservation Science, Arizona State University, Tempe, AZ 85281, USA

\section{S. A. Bakar}

Sabah Wildlife Department, Wisma Muis, Block B, 5th Floor, 88100 Kota Kinabalu, Sabah, Malaysia

\section{B. Goossens}

Sustainable Places Research Institute, Cardiff University, Cardiff CF10 3BA, UK
Objectives We explored the influence of landscape characteristics on the fine-scale space-use patterns of a model generalist carnivore, the Malay civet (Viverra tangalunga), within degraded tropical forests and oil palm plantations.

Methods We collected over 20,000 GPS locations from 21 male civets in Sabah, Malaysian Borneo to evaluate the species' space-use patterns and habitat utilization processes. We used movement-based modeling to determine home ranges, and combined the results with high-resolution remotely sensed habitat characteristics. We developed resource utilization functions to determine individual and populationlevel functional responses to proximity to plantation edge, distance to water, terrain ruggedness, forest structure, and functional diversity.

Results Civets foraged within oil palm plantations, yet all animals utilized forests. Home ranges scaled with proportion of plantation within both total and core ranges. Resource utilization functions reported individualism in the species' responses to habitat characteristics. At the population-scale, civets consistently and more intensely used habitats closer to plantation edges and taller tree canopies.

Conclusions Although plantations did not pose an inhospitable matrix, oil palm agriculture is a less suitable habitat than remnant forests for civets. Proximity measures and forest structure influenced the spatial behaviors of this adaptable generalist, highlighting the importance of protected areas. We 
recommend land-sparing and -sharing approaches to facilitate carnivore persistence across oil palm degraded landscapes.

Keywords Resource utilization function - Home range $\cdot$ Oil palm plantation - Agriculture $\cdot$ Landscape fragmentation $\cdot$ Malay civet

\section{Introduction}

Land cover change is extensive, with over $40 \%$ of global terrestrial land converted to human-dominated uses (Foley et al. 2005; Ellis and Ramankutty 2008). Mammalian carnivore populations are in decline worldwide (Ripple et al. 2014), and agricultural land use is highlighted as a significant driver of extinction events (Dobrovolski et al. 2013). As a guild, carnivores are considered particularly sensitive to landscape changes due to traits such as long lifespans, slow reproduction rates, high trophic positions, large home ranges, and low metapopulation densities (Keinath et al. 2017). The full extent of carnivore responses to human modified landscapes is, however, dependent on the ecology of the focal species (Ryall and Fahrig 2006). Within the guild, generalists display elevated plasticity to land use modifications compared to specialists (Gehring and Swihart 2002), with a range of species adapting to life across gradients of human disturbance (e.g. Bouyer et al. 2014; Jerosch et al. 2017; Suraci et al. 2019).

The ecological consequences of land use changes are a function of the interplay between a species' adaptability and the configuration of altered landscapes. Following human modification, the size, shape, composition, and connectivity of remaining natural habitats affect carnivores by either limiting or facilitating animal movement (Crooks et al. 2011). As an example, agricultural land flanked by or containing remnant habitat patches displays enhanced carnivore occupancy (Santos et al. 2016). Persistence can be further facilitated by the degree of functional impedance posed by the agricultural land use itself; if the matrix is permeable to, or can be successfully utilized by a species, a population's survival probability further increases (Ferreira et al. 2018). Through the quantification of carnivore movements within heterogeneous landscapes, scientists, resource managers, and conservationists gain explicit and mechanistic insights into the habitat requirements of species persisting alongside agriculture (Nathan et al. 2008; van Moorter et al. 2016). These insights, in turn, inform more effective management actions, such as establishment of protected areas (Desmet 2018), implementation of land-sharing schemes within agriculture itself (Perfecto and Vandermeer 2008), or creation of functionally optimized wildlife corridors (Chetkiewicz and Boyce 2009).

Oil palm (Elaeis guineensis) agriculture is a significant driver of tropical forest loss and degradation (Phalan et al. 2013). Relative to highly diverse primary forests, the establishment of oil palm plantations results in marked declines in species' abundances, assemblage complexity, and fundamental ecosystem functions (Dislich et al. 2017). Forest specialists with restricted dietary niches or behaviors cannot adapt to agricultural conversion (Foster et al. 2011). As such, species that do persist within the monoculture are often generalists (be it in dietary or habitat terms), pests, or invasive (Rembold et al. 2017). Given the forecasted increases in global agricultural degradation (Tilman et al. 2001), it is crucial to understand how generalists utilize these landscapes and what actions, if any, may be taken to facilitate biodiversity retention (Sodhi et al. 2010).

The island of Borneo is a biodiversity hotspot (Myers et al. 2000), yet is experiencing one of the highest deforestation rates due to oil palm agriculture (Gaveau et al. 2019). A total of 25 small- to mediumsized carnivore species are found in Borneo, representing one of the richest co-existing extant guilds in the world (Ross et al. 2017). The guild includes a spectrum of forest specialist and generalist species; the island has been highlighted as a region of carnivore conservation priority (Schipper et al. 2008). Effective management of the guild, however, is hindered by a paucity of knowledge regarding the ecology and behaviors of these species, particularly tolerance and fine-scale responses to human-modified landscapes (Mathai et al. 2016). Studies report limited carnivore flexibility to oil palm plantations, such as distinct avoidance by GPS collared Sunda clouded leopards (Neofelis diardi; Hearn et al. 2018). Most research thus concludes the guild will only be sustained with strict land-sparing conservation efforts (e.g. Yue et al. 2015; Wearn et al. 2017). However, documentation of several generalist species in close proximity to and 
within oil palm plantations suggests there are more nuanced processes facilitating carnivore persistence (Jennings et al. 2015; Evans et al. 2016a). One such species is the Malay civet (Viverra tangalunga), a 3-7 kg ground-dwelling, nocturnal, and predominantly solitary carnivore recorded in a range of habitat types, including within oil palm plantations (Duckworth et al. 2016). With advancements in animal tracking technologies, an unprecedented quantity and quality of spatiotemporal movement data can be directly collected from the species (Evans et al. 2016b). This opportunity facilitates the explicit study of carnivore functional responses to degraded and heterogeneous landscapes, which will provide insights into ecological mechanisms of carnivore persistence.

We quantified the spatial movements and habitat use of Malay civets, a generalist carnivore persisting within the degraded lowland forest fragments and oil palm plantations of northeastern Borneo. We combined animal movement data from GPS collars with high-resolution remotely sensed landscape characteristics to investigate the patterns and underlying landscape drivers of civet space use. Specifically, we sought to identify if oil palm plantations were permeable to civet movements, and if so, to determine the extent of usage. We then related patterns of core and total home range sizes to an individual's use of oil palm agriculture to determine habitat suitability. We explored how habitat utilization of civets varied in response to proximity to agricultural and natural edges, terrain ruggedness, forest structure, and forest functional diversity. We sought to provide insights into effective conservation management strategies to facilitate carnivore persistence across agriculturally modified landscapes.

\section{Methods}

Study area

The research was conducted in the Lower Kinabatangan Floodplain in eastern Sabah, Malaysian Borneo (approximate range: $5^{\circ} 18^{\prime} \mathrm{N}$ to $5^{\circ} 42^{\prime} \mathrm{N}$ and $117^{\circ} 54^{\prime}$ $\mathrm{E}$ to $118^{\circ} 33^{\prime} \mathrm{E}$; Fig. 1). The Kinabatangan River is Sabah's largest river, stretching $560 \mathrm{~km}$ and encompassing a total catchment area of 1.68 million ha (Harun et al. 2015). Selective logging for economically viable trees began in the 1950s and marked the beginning of the region's large-scale forest degradation (McMorrow and Talip 2001). The wet tropical climate and alluvial soils are highly suitable for oil palm cultivation (Pirker et al. 2016), and the establishment of large-scale plantations began in the early 1980s. The majority of the forests in the Floodplain have been converted into oil palm plantations (Francis 2017), and the Kinabatangan estates account for $28 \%$ of Sabah's total cultivated area of oil palm crop (Abram et al. 2014). The remaining patches of natural land cover flanking the river comprise a mixture of dry lowland, semi-inundated, swamp, and riparian forests interspersed with small grasslands. As of 2014, over 98\% of the remaining forested areas in the Floodplain were within $1 \mathrm{~km}$ of a forest edge (Francis 2017).

Within this mosaic landscape is the 27,000 ha Lower Kinabatangan Wildlife Sanctuary. The Sanctuary is composed of 10 forest lots of varying degrees of isolation and disturbance history. The protected area network includes seven Forest Reserves, and in combination with the Sanctuary, sums to approximately 45,000 ha along $150 \mathrm{~km}$ of the lower reaches of the river (Fig. 1). An estimated 30,000 ha of additional forest exist outside protected areas on private or state lands (Abram et al. 2014). This research occurred within the Sanctuary lots 5, 6, and 7 and the surrounding oil palm estates. The Lower Kinabatangan Floodplain thus represents an ideal landscape to assess biodiversity persistence to forest fragmentation and degradation by oil palm plantations.

\section{Civet GPS collaring}

Live trapping began in October 2013 and was completed in December 2019. We captured civets using either custom-built box traps or commercial spring-loaded traps nocturnally set to avoid capture of non-target diurnal wildlife. Civets were anesthetized by a qualified veterinarian and fitted with GPS collars (e-obs 1A, e-obs GmbH, Gruenwald, Germany) set to collect hourly positions from 18:00 through 06:00. Successful trapping occurred across the study area, and collars were deployed within remnant forest 'blocks' (i.e. Sanctuary lots 6 and 7), narrow forest corridors (i.e. Sanctuary lot 5), and directly along plantation boundaries; all animals were captured within $3 \mathrm{~km}$ of an oil palm plantation. All collared individuals were male, with the exception of one 


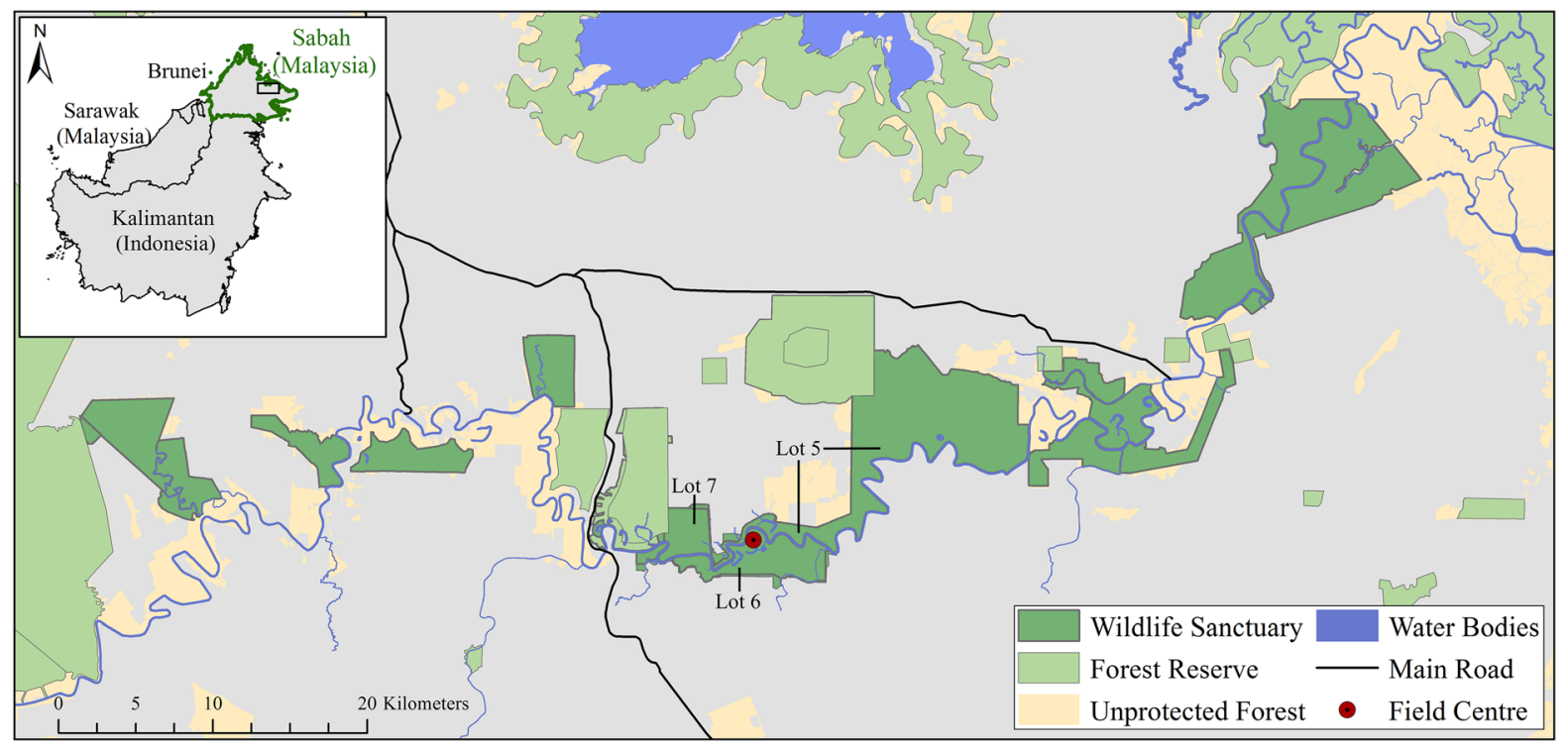

Fig. 1 Map of the Lower Kinabatangan Floodplain showing the protected areas and field centre (Danau Girang Field Centre) in Sabah, Malaysian Borneo. The gray areas in the main map

experimental deployment on a female, due to morphometric constraints (head:neck circumference ratios were sexually dimorphic, and it was difficult to safely collar females; Supplementary Table 1). For further capture methodology, anaesthesia protocols, and tag specifications, see details provided in Evans et al. (2016b). All animal handling protocols were approved by the Sabah Wildlife Department and the Sabah Biodiversity Centre (license ref.no: JKM/ MBS.10000-2/2 JLD.6[8]). Capture techniques and GPS collar deployment followed the guidelines set by the American Society of Mammalogists (Sikes et al. 2016).

\section{Civet space use}

Civet space use was assessed using the biased random bridges (BRB) model, a movement-based home range estimator that accounts for the spatial and temporal information of GPS collar data (Benhamou and Cornélis 2010; Benhamou 2011). This estimator produces a 3-dimensional probabilistic map of animal space use, called a utilization distribution (UD), which quantifies the relative intensity of animal space use within a landscape. The method develops UDs from an animal's movement paths rather than discrete point clouds, producing highly informative models of space denote non-forested land classes dominated by oil palm plantations and small settlements; specifically labeled lots indicate the focal study area

use well suited to assessments of habitat utilization. The selection and optimization of three parameters (maximum time threshold $T_{\max }$, minimum step length $L_{\text {min }}$, and minimum smoothing parameter $h_{\text {min }}$ ) within the modeling framework accounted for the serial autocorrelation in civet tracking data and the locational error of the GPS units. The same values were applied to all individuals in the study. Briefly, $T_{\max }$ was set to $7800 \mathrm{~s}(2 \mathrm{~h}$ plus $10 \mathrm{~min}$ of tolerance to account for variable GPS fix times). Based on the results of collar accuracy testing (Evans et al. 2016b), $L_{\min }$ was set to $17 \mathrm{~m}$. Following the protocols presented by Benhamou (2004) and Benhamou and Cornélis (2010), $h_{\min }$ was set to $40 \mathrm{~m}$. Civet UDs were constructed at $10 \mathrm{~m}$ resolution, and total and core home ranges designated as the area encompassed by the $90 \%$ and $50 \%$ contours, respectively, as recommended per Börger et al. (2006). All 18:00 h fixes were removed prior to analyses to account for the spatial pseudo-replication of diurnal sleeping sites within the data structure; thus, models represent 'active' nocturnal civet ranges. For those individuals that were collared twice, data from the longest running unit deployment were used in BRB analyses. Home range models were developed with $\mathrm{R}$ v3.5.0 and the adehabitat packages (Calenge 2006). 
Table 1 Resources included as environmental covariates in resource utilization functions evaluating space use of Malay civets (Viverra tangalunga) at the home range scale

\begin{tabular}{|c|c|c|}
\hline Resource; shorthand & Definition & Justification \\
\hline \multicolumn{3}{|c|}{ Landscape configuration metrics } \\
\hline $\begin{array}{l}\text { Distance to oil palm } \\
\text { plantation edge; } \\
\text { plant }\end{array}$ & $\begin{array}{l}\text { Euclidean distance to nearest accessible oil palm } \\
\text { plantation edge; in } \mathrm{m}\end{array}$ & $\begin{array}{l}\text { Anthropogenic edges may concentrate civet dietary } \\
\text { resources through edge effect processes. } \\
\text { Alternatively, civets may avoid plantation } \\
\text { disturbances. This metric is a proxy for extent and } \\
\text { relative size of forest and oil palm plantation } \\
\text { features }\end{array}$ \\
\hline $\begin{array}{l}\text { Distance to water; } \\
\text { water }\end{array}$ & $\begin{array}{l}\text { Euclidean distance to nearest accessible waterway } \\
\text { (Kinabatangan River or semi-permanent tributary); } \\
\text { in } \mathrm{m}\end{array}$ & $\begin{array}{l}\text { Metric identifies and controls for potential civet } \\
\text { preferences for natural forest edges, such as } \\
\text { riparian boundaries, across the landscape }\end{array}$ \\
\hline \multicolumn{3}{|l|}{ Landscape topography } \\
\hline $\begin{array}{l}\text { Vector ruggedness } \\
\text { measure; VRM }\end{array}$ & $\begin{array}{l}\text { A calculated metric of terrain ruggedness } \\
\text { (Sappington et al. 2007). Values close to } 0 \text { indicate } \\
\text { level terrain, with increasing values relating to } \\
\text { increasing ruggedness. Derived from } 2 \mathrm{~m} \\
\text { resolution digital terrain model }\end{array}$ & $\begin{array}{l}\text { As this is a lowland system, civets may avoid flood- } \\
\text { prone areas at the fine scale. Oil palm plantation } \\
\text { drainage ditches may provide cover or concentrated } \\
\text { foraging grounds for civets }\end{array}$ \\
\hline \multicolumn{3}{|c|}{ Forest canopy structural attributes } \\
\hline $\begin{array}{l}\text { Mean top of canopy } \\
\text { height; mTCH }\end{array}$ & $\begin{array}{l}\text { Mean top of canopy height within circular buffer of } \\
10 \mathrm{~m} \text { radius aligned with each pixel of an } \\
\text { individual's utilization distribution; in m. Derived } \\
\text { from } 2 \mathrm{~m} \text { resolution top of canopy layer }\end{array}$ & $\begin{array}{l}\text { Indicator of forest structure, successional age, and } \\
\text { quality in the degraded Kinabatangan landscape; } \\
\text { metric provides a proxy of ecological } \\
\text { heterogeneity, which may influence food } \\
\text { distribution and rest structures for civets. Positively } \\
\text { correlated with canopy cover, providing relative } \\
\text { estimation of canopy closure and vertical forest } \\
\text { complexity }\end{array}$ \\
\hline $\begin{array}{l}\text { Standard deviation } \\
\text { of top of canopy } \\
\text { height; sdTCH }\end{array}$ & $\begin{array}{l}\text { Measure of canopy height heterogeneity within } \\
\text { circular buffer of } 10 \mathrm{~m} \text { radius aligned with each } \\
\text { pixel of an individual's utilization distribution; in } \\
\text { m. Derived from } 2 \mathrm{~m} \text { resolution top of canopy layer }\end{array}$ & $\begin{array}{l}\text { Proxy for degree of forest canopy heterogeneity, } \\
\text { which influences biodiversity measures in forest } \\
\text { landscapes }\end{array}$ \\
\hline \multicolumn{3}{|l|}{ Forest beta diversity } \\
\hline $\begin{array}{l}\text { Forest functional } \\
\text { class; F value }\end{array}$ & $\begin{array}{l}\text { Categorical metric of forest functional class; from } 0 \\
\text { to } 32 \text {. See Brodrick et al. (in review) for } \\
\text { methodologies and class descriptions. Interpolated } \\
\text { from } 30 \mathrm{~m} \text { resolution forest functional class raster }\end{array}$ & $\begin{array}{l}\text { Measure of forest beta diversity; indicates changes in } \\
\text { botanic composition, which may influence civet } \\
\text { dietary resource (i.e. fruit and prey) distribution, } \\
\text { quality, or availability }\end{array}$ \\
\hline
\end{tabular}

Differences in the mean home range sizes of civets that entered oil palm plantations, and those that did not, were evaluated with Welch's two sample t-tests. The relationship between home range size and the proportion of the home range contour containing oil palm was assessed using a general linear model (GLM). Models were fitted with a Gaussian error distribution and identity link function, and modeling assumptions assessed and met by optimizing standardized residual plots.

\section{Habitat resource mapping}

We mapped the landscape of the Lower Kinabatangan Floodplain in 2016 using the Global Airborne Observatory (GAO; formerly the Carnegie Airborne Observatory; Asner et al. 2012). The GAO is a mapping system utilizing laser-guided image spectroscopy through the simultaneous aerial deployment of a light detection and ranging (LiDAR) scanner and a visibleto-shortwave infrared (VSWIR) imaging spectrometer. The observatory contains a Global Positioning System-Inertial Measurement Unit to facilitate high 
levels of locational precision and accuracy in the data collection process. The LiDAR system produces high resolution, three-dimensional information of terrain and vegetation structure (Lefsky et al. 2002). Measures of vegetative radiance collected by the VSWIR provide insights into forest canopy functional traits and landscape beta diversity (Asner et al. 2017).

Data were collected at $3600 \mathrm{~m}$ above ground level at a velocity of 150 knots. Details of the LiDAR data acquisition, specifications, and processing can be found in Asner et al. (2018). The VSWIR spectrometer collected radiance signatures across 428 continuous spectral channels within the 350-2510 nm wavelength range (Asner et al. 2012). The sensor held a $34^{\circ}$ fieldof-view and provided radiance measures at $4 \mathrm{~m}$ resolution. Details regarding the processing of VSWIR image spectra and field calibration and validation protocols are described in Martin et al. (2018). In that work, the spectra were converted to verifiable estimates of canopy foliar chemical properties. Using the same methods of Asner et al. (2017), forest functional diversity classes were mapped by Brodrick et al. (in review) using K-means clustering of canopy foliar chemical traits. These analyses yielded a Sabah-wide map of 32 unique forest functional classes reported at a mapping resolution of $30 \mathrm{~m}$.

\section{Resource utilization functions}

The landscape features influencing civet space use were assessed through the development of resource utilization functions (RUFs) calculated at the total (90\%) home range extent (thus representing thirdorder selection, Johnson 1980). RUFs relate variations in an animal's continuous and probabilistic utilization distribution (UD) surface to the underlying, spatially explicit environmental covariates (Marzluff et al. 2004; Millspaugh et al. 2006). Notably, this approach robustly minimizes habitat-induced fix biases and location uncertainties inherent in all GPS telemetry studies (Millspaugh et al. 2006; Hooten et al. 2013). Individual RUFs were calculated for each civet in a multiple regression framework as described by Marzluff et al. (2004) using the ruf package (Handcock 2015). This package allows models to account for the spatial autocorrelation in use values of adjacent UD pixels through the application of a Matern correlation function; following recommendations of Marzluff et al. (2004), the spatial dependence was set at $40 \mathrm{~m}$ and the smoothness of each surface at 1.5 for all animals. Each pixel value within an individual's range was rescaled to a use metric between 1 (lowest use) and 99 (highest use) based on the relative volume of the UD (Kertson and Marzluff 2010). We log-transformed these values to meet assumptions of normality prior to analysis (Hooten et al. 2013).

We initially selected eight landscape characteristics (hereafter 'resources') as measures we expected to influence civet habitat utilization based on local expert opinion and literature of carnivore behaviour (Table 1). Each of these assessed parameters may influence civet space use by providing food, mitigating predation risks, or acting as cover from environmental conditions. Resources were described by one of four categories: landscape proximity metrics, landscape topography measures, forest canopy attributes, and forest beta diversity class. Civet space-use models and remote sensing data products were processed in $\mathrm{R}$ software and QGIS v3.10. Shapefile layers of oil palm plantation boundaries and waterways were created from Google Earth Pro satellite imagery to derive distances from the center of each UD pixel to the closest accessible feature. These Euclidean distances accounted for accessibility by taking into consideration that collared civets did not cross the main river.

We interpolated our selected metric of landscape topography [the vector ruggedness measure, VRM (Sappington et al. 2007)] from the GAO digital terrain model, and measures of forest canopy structure (average canopy height, heterogeneity of canopy height, and canopy cover) from the top of canopy height raster. A circular analysis window with a $10 \mathrm{~m}$ radius was centered on each UD cell to calculate the mean and standard deviation of canopy height values. Canopy cover was measured as the percent of canopy height pixels within this window less than $10 \mathrm{~m}$ in height. We extracted forest beta diversity values from Brodrick et al.'s (in review) forest functional class map for each UD pixel.

Collinearity between explanatory resources was assessed with Pearson correlations at the level of each individual's dataset. Canopy cover was excluded from RUF analyses due to collinearity ( $|r|>0.7)$ with mean canopy height across all civet datasets. Resource parameters were transformed to meet normality assumptions. Specifically, distance to water and plantations, as well as the mean and standard deviations of canopy height, underwent a square root 
transformation. Vector ruggedness measure was $\log$ transformed. The same model structure and transformations were used for each civet's RUF.

The standardized resource coefficients $(\beta)$ from civet RUFs were used to produce a population-level assessment of Malay civet space use. We calculated the mean standardized coefficient $\left(\beta^{*}\right)$ and $95 \%$ confidence interval $(\mathrm{CI})$ for each resource, such that CIs encompassed inter-animal variation (Marzluff et al. 2004). Resources with $95 \%$ CIs that did not include zero were considered significant predictors of intense use at the population-level (Marzluff et al. 2004). The magnitude of statistically significant mean standardized coefficients indicated the relative importance of the resource in determining intensity of use by Malay civets (Millspaugh et al. 2006).

\section{Results}

Space use by Malay civets

A total of 24 GPS collars were deployed on 21 Malay civets, resulting in the collection of 20,834 successful GPS fixes (Supplementary Table 1); three individuals were collared twice due to prematurely lost or malfunctioning units. Data collection spanned 1-246 nights (mean \pm SE: $105 \pm 15$ nights). Based on the unit failures of Female 1 and Male 5, these datasets were omitted from further analyses; all results thus describe the space-use patterns of male Malay civets.

Total home ranges (90\% contours) varied in size from 45.9 to 214.8 ha (mean \pm SE: $113.4 \pm 13.8$ ha; Supplementary Table 1). Core home ranges $(50 \%$ contours) measured from 12.2 to 75.3 ha (mean \pm SE: $35.8 \pm 5.20$ ha). Eight civets did not enter oil palm plantations during the collaring period, while 11 individuals utilized both forested and plantation land cover (Fig. 2). The presence of oil palm within home ranges varied within the population (Fig. 3); across all individuals, the median percentage of total home range containing plantation was $15.3 \%$ (range $0-67.8 \%$ ). The median percentage of a civet's core home range comprising oil palm was $17.2 \%$ (range $0-79.8 \%)$.

Civets that accessed oil palm plantations held significantly larger total and core home ranges than those individuals that remained in the forests $(\mathrm{t}=-3.913, \quad$ d.f. $=14.801, \quad p<0.005$; $\mathrm{t}=-3.689$, d.f. $=13.665, p<0.005$, respectively). Mean $( \pm \mathrm{SE})$ total and core home range sizes for civets that accessed oil palm were $136.5 \pm 52.9$ ha and $43.2 \pm 6.02$ ha, respectively. In contrast, the mean $( \pm \mathrm{SE})$ total and core home range sizes for civets that used only forests were $65.7 \pm 8.52$ ha and $18.8 \pm 2.71$ ha, respectively.

There was a significant positive relationship between the overall range size and the percentage of the total home range containing oil palm $\left(\mathrm{F}_{1,17}=23.8\right.$, $p<0.0005$, Adj. $\mathrm{R}^{2}=0.559$; Fig. 4a). A $10 \%$ increase in the percentage of oil palm within an individual's total range resulted in an overall increase of range size by $9.7 \pm 4.03$ ha $(t=4.879$, $p<0.0005)$. Similarly, there was a significant positive relationship between the core range area and the percentage of the core range containing oil palm $\left(\mathrm{F}_{1,17}=13.68, p<0.005\right.$; Adj. $\mathrm{R}^{2}=0.413$; Fig. $\left.4 \mathrm{~b}\right)$. A $10 \%$ increase in the percent of oil palm within a civet's core range resulted in the core range increasing by $4.6 \pm 1.2$ ha in area $(t=3.699, p<0.005)$.

\section{Resource utilization functions}

Nineteen resource utilization functions were calculated from civet collar data, and resource use was variable at the individual scale (Fig. 5). At the population-level, intensity of civet space use consistently increased with increasing proximity to oil palm plantation edges (89.5\% of individuals) and with increasing height of forest canopy $(63.2 \%$ of individuals; Fig. 5, Supplementary Table 2). Distance to plantation edge was the most important resource predicting intensity of space use by civets, followed by mean top of canopy height. No other landscape resources were consistently correlated with civet use intensity at the population level.

\section{Discussion}

This study presents the first detailed insights into the influences of oil palm plantations and remnant protected forests on the spatial ecology of male Malay civets. Our merging of high spatiotemporal resolution GPS tracking and mapped habitat data allowed us to quantify patterns of generalist persistence in degraded landscapes. Plantations did not act as definitive barriers to movement; indeed, a majority of civet 


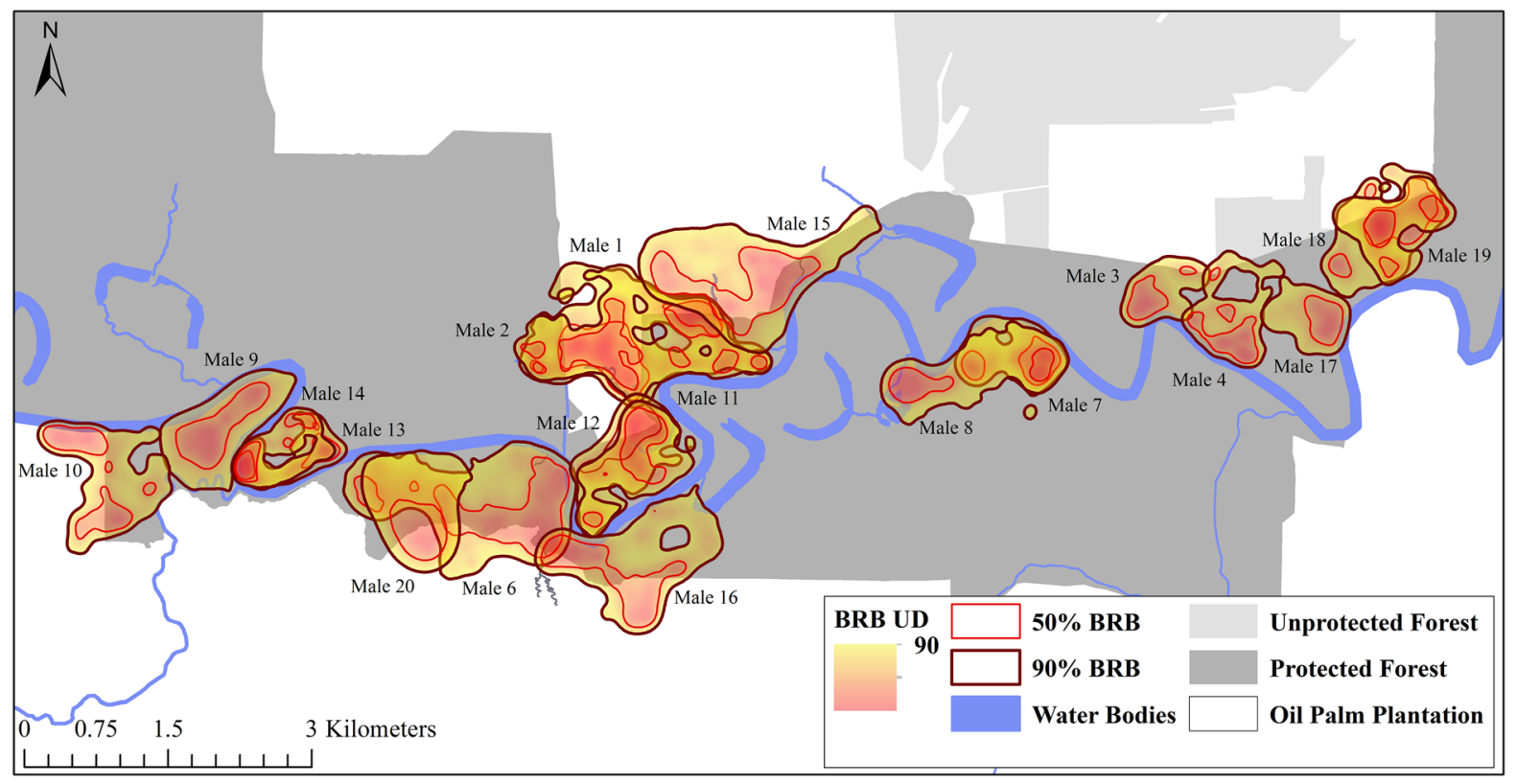

Fig. 2 Space-use models for Malay civet (Viverra tangalunga) males calculated from biased random bridges (BRB) approach within the Lower Kinabatangan Floodplain from 2013 to 2020. Maps show each individual's utilization distribution (UD)

home ranges contained oil palm plantations. However, all animals in this study used protected remnant forests, emphasizing the likely value of these features for conservation. Proximity to plantation edges and forest canopy height were important features explaining intensity of space use by civets, highlighting the significance of proximities and local habitat attributes in shaping this species' adaptability. Overall, our analyses indicate oil palm is a less suitable habitat for civets than remnant forest, but persistence within degraded landscapes may be met with a combination of land sharing and land sparing approaches.

Malay civet access of oil palm plantations confirms the species' ability to forage within this agricultural matrix. Our work builds upon previous studies documenting civet presence within oil palm plantations (Jennings et al. 2010; Yue et al. 2015), and is the first to detail the extent to which this generalist uses human-modified lands. Plantation boundaries did not impede civet movements; in fact, individuals actively used oil palm agriculture at both the total and core home range scales. By quantifying the explicit spaceuse patterns of these animals across the heterogeneous landscape, our work provides preliminary mechanistic insights into the adaptability of this species to surface clipped at $90 \%$; each raster is overlaid with contour outlines delineating the boundaries of core $(50 \%)$ and total (90\%) home ranges

plantations, with individuals demonstrating a range of tolerance thresholds (Fig. 3). As Malay civets are considered dietary generalists (Colón and Sugau 2012), plantations likely provide supplemental food resources such as oil palm fruit or associated small mammals. Indeed, given their dietary flexibility, Malay civets may supply a degree of rodent-control service to oil palm plantations (e.g. Holzner et al. 2019), providing a conservation incentive to industry stakeholders.

Despite this behavioral flexibility, however, the positive correlations between home range size and extent of oil palm usage indicate plantations are of lower suitability than forested habitats. Carnivore home range size is negatively related to habitat suitability, a term encompassing resource quality, stability, and predictability at the scale of an individual's perception (McLoughlin and Ferguson 2000). To obtain adequate resources within plantations, male civets cover larger areas, and thus expend more energy, than those individuals exclusively using forest fragments. Similar scaling patterns have been documented in other spatially adaptive carnivores using agriculture (e.g. Eurasian lynx Lynx lynx, Aronsson et al. 2016; feral cat Felis catus, Bengsen et al. 2016; 


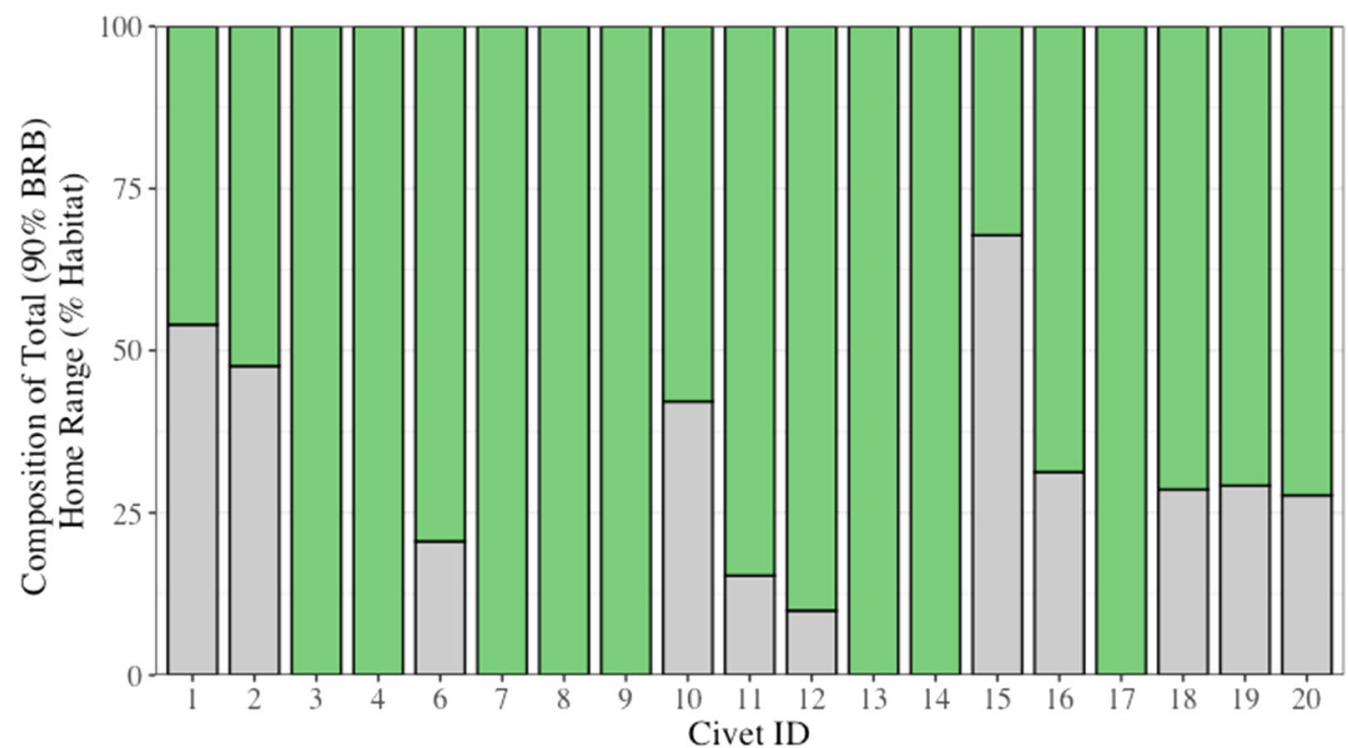

Habitat

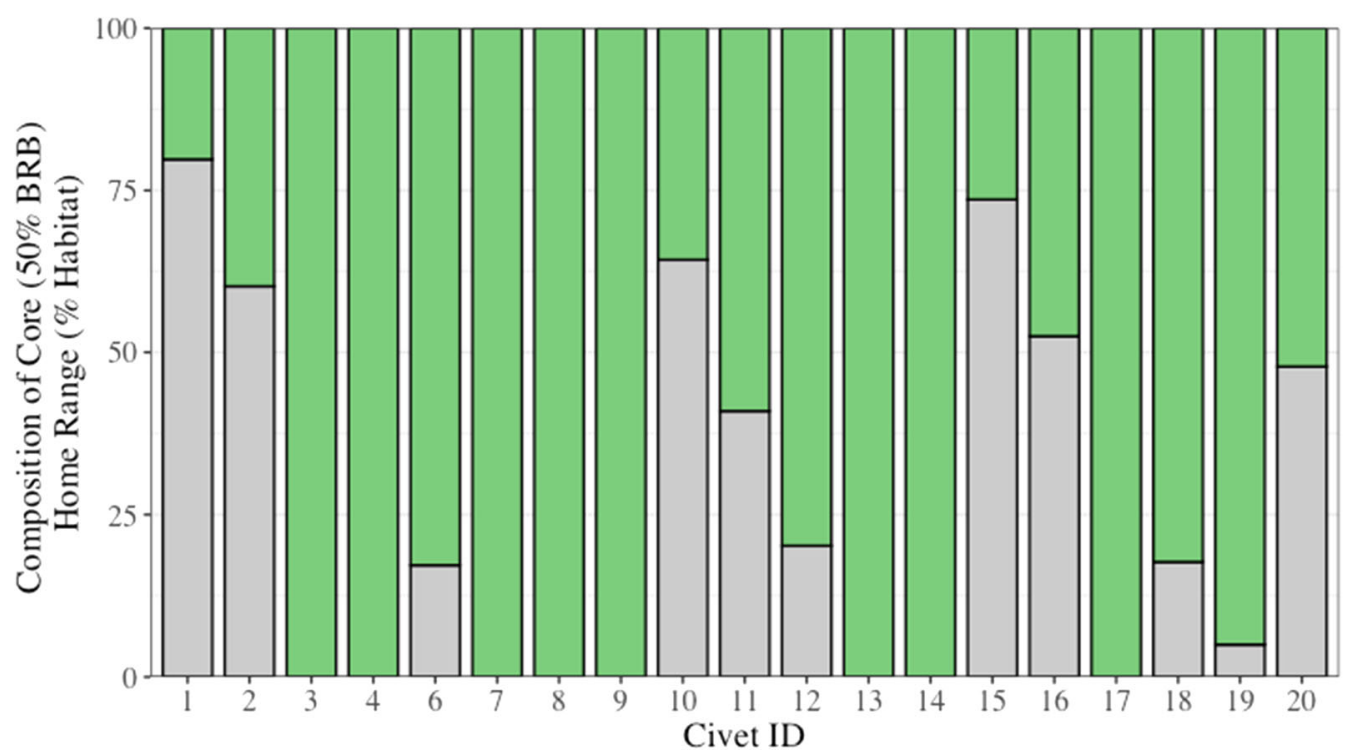

Fig. 3 Habitat composition of total (90\%) and core (50\%) biased random bridges (BRB) home ranges of 19 Malay civet (Viverra tangalunga) males in the Lower Kinabatangan Floodplain, Sabah, Malaysia

red fox Vulpes vulpes, Walton et al. 2017), and represent the ecological costs of adaptation to modified landscapes. Mechanistically, risks not assessed in this study may offset civet foraging rewards obtained within oil palm plantations; bushmeat hunting, road accidents, conflict with domestic animals, and exposure to agrochemicals are greater within plantations (Azhar et al. 2013; Salim et al. 2014).

Concurrently, each civet in this study utilized remnant forest patches, suggesting even this generalist species likely requires a degree of access to natural habitats. The conservation value of protected patches and riparian corridors such as the Lower Kinabatangan Wildlife Sanctuary has been reported in other anthropogenically-altered ecosystems (Wintle et al. 2019), but is frequently debated within the context of oil palm research (e.g. Yue et al. 2015; Wearn et al. 2017; Pardo et al. 2019). Our results provide further evidence that generalist carnivore persistence within oil palm landscapes may require small patches of even degraded forests outside of plantation boundaries (i.e. landsparing); such features likely provide source habitats 




Fig. 4 Predicted relationship between the size of Malay civet (Viverra tangalunga) a total $(90 \%)$ and b core $(50 \%)$ biased random bridges (BRB) home ranges and percent of range containing oil palm plantation. Points are the recorded values

from which civets may 'spillover' to forage within oil palm plantations (Blitzer et al. 2012).

Moreover, with all other landscape variables held constant, areas with greater forest canopy height were more intensively used by civets. Top of canopy height is a proxy of forest quality, particularly in disturbed systems such as the Kinabatangan (Davies et al. 2017), suggesting this species positively responds to higher quality and less degraded forests whenever available. By principles of the environmental heterogeneity hypothesis (Simpson 1949), forests with taller canopies contain more ecological niches than comparatively simplified systems (Tews et al. 2004); wildlife diversity and species' reproductive success have been positively related to elevated canopy height (Hinsley et al. 2006; Bergen et al. 2009). The interaction between 3-dimensional habitat metrics and animal movement ecology represents an expanding field (Davies and Asner 2014), and our study provides preliminary evidence of a ground-dwelling generalist functionally responding to forest structure within a degraded system. Taller fruiting trees, such as Ficus spp., may provide a large volume of reliable food for many lowland animals, civets included (Nakabayashi et al. 2017). Alternatively, these areas of higher quality forests may act as thermally optimized foraging grounds (Melin et al. 2014), provide adequate

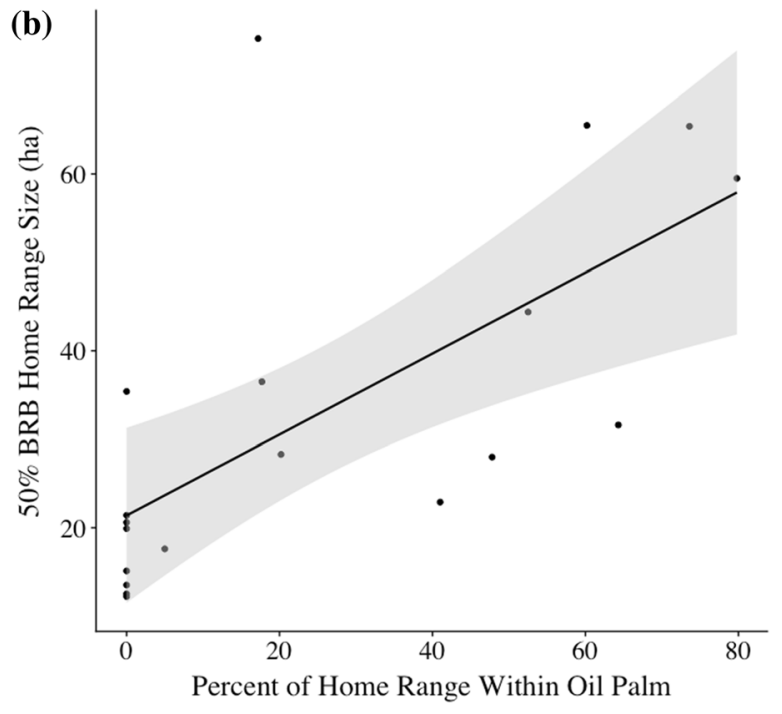

from the 19 independent males. Solid lines indicate model estimates, and the shaded regions represent the $95 \%$ confidence intervals of the model

ground and mid-story vegetative cover, or concentrate female distributions around reproductive denning sites (Zhao et al. 2012); further research is warranted to uncover the specific structural drivers behind spaceuse patterns of Malay civets.

Intriguingly, there was no evidence of populationlevel consistency in civet responses to any of the assessed forest functional classes, suggesting forest structure may be more important than functional composition in determining civet use. This is likely borne from the high variability in civet responses and access to forest functional classes (Fig. 5). This large degree of individualism may exemplify the flexibility of this adaptable habitat generalist within the anthropogenically-altered Kinabatangan landscape; similar patterns have been recorded in both large and small carnivores [e.g. cougars Puma concolor, (Kertson and Marzluff 2010; Kertson et al. 2011), common genets Genetta genetta, (Santos et al. 2016)]. Alternatively, it is possible the vegetative diversity encompassed by this metric may not adequately capture resources used by civets. Taken all together, these findings may carry implications for landscape planning actions within degraded regions, such as protected area establishment or restoration efforts, by demonstrating this species is likely to respond positively to small increases in forest 


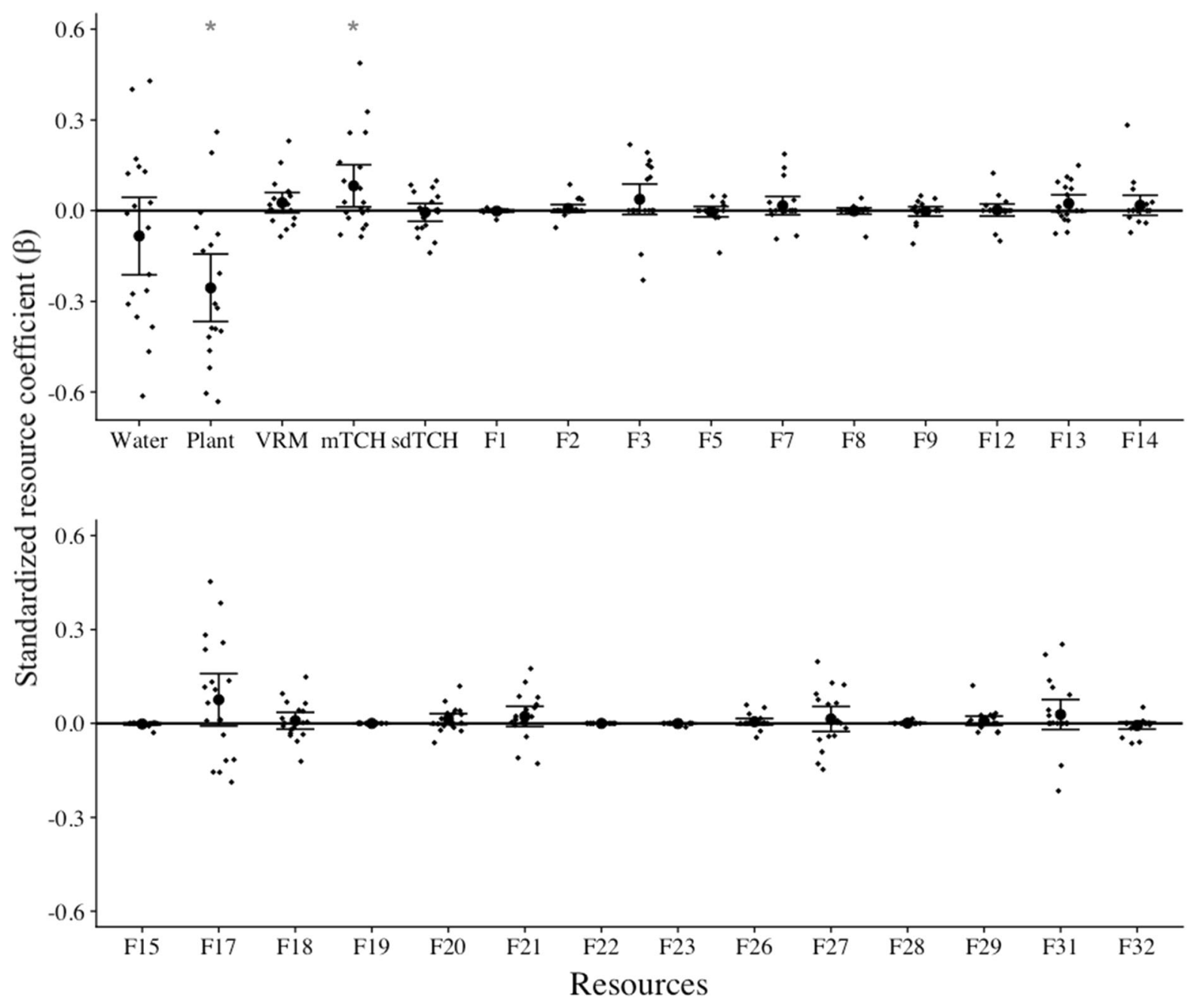

Fig. 5 Standardized resource coefficients $(\beta)$ from Malay civet (Viverra tangalunga) resource utilization function (RUF) models. Large points indicate the population-level mean $\beta^{*}$, and error bars represent the $95 \%$ confidence intervals. Negative $\beta$ values indicate civet use increased when continuous resource metrics were smaller, while positive $\beta$ values indicate civet use increased when metrics were greater. Negative $\beta$ values for forest functional classes indicate the class is used less than

canopy, regardless of explicit vegetative beta diversity.

At the population-level, civet landscape use was most strongly influenced by proximity to oil palm agricultural edges. Elevated use of edge habitats by carnivores has been documented in other humanmodified systems (e.g. Pereira and Rodríguez 2010; Andersen et al. 2017), and suggests landscape proximity metrics may modulate civet persistence across the degraded Kinabatangan Floodplain. As this metric expected based on availability, while a positive $\beta$ value indicates use of the class is greater than expected based on availability; the reference category is areas with no canopy cover. Asterisks indicate a statistically significant population-level effect. Water distance to water, Plant distance to oil palm edge, VRM vector ruggedness metric, $m T C H$ mean top of canopy height, $s d T C H$ standard deviation of top of canopy, $F$ relates to categorical forest functional class numbers from Brodrick et al. (in review)

is non-directional relative to land cover (i.e. forest vs. plantation), this pattern may be explained by two processes. First, given civet use of both forests and plantations, repeated movements between protected areas and plantations are likely to elevate the relative importance of edge zones at the home range scale. This supports the camera trap findings of Jennings et al. (2015), whereby Malay civet occupancy within Indonesian plantations was positively related to the distance from native forest boundaries. Free roaming 
packs of domestic dogs within most Kinabatangan oil palm plantations may pose a predation threat to foraging civets; individuals may thus not forage too far from the protection provided by natural forest cover. In this case, civet persistence within oil palm plantations is directly facilitated by access to remnant forests, underlining the importance of landscape configuration in carnivore adaptability. Alternatively, civets within remnant forest fragments may positively respond to plantation-induced edge effects. Ordway and Asner (2020) documented significant alterations to the structure and functioning of Malaysian forests flanking oil palm plantations. Such changes may benefit generalists like Malay civets by providing localized increases in small mammal densities (Sálek et al. 2010) or fruit production by edge-preferring vines (Lovejoy et al. 1986). Given the positive relationship between canopy height and civet intensity of space use, however, other factors not explicitly assessed in the resource utilization function analyses may more eloquently explain these forest edge patterns.

Our results have several important caveats. Variables not explicitly accounted for in this study, such as the position of female civet ranges, conspecific densities, oil palm management strategies, temporal variations in forest phenology, or forest understory structure are likely to influence space-use patterns of male civets. Furthermore, within resource utilization functions (RUF), relationships between habitat resource proxies and intensity of space use are treated as linear functions, which may mask ecologically nuanced civet responses to continuously varying landscape characteristics and associated resources (e.g. Garabedian et al. 2017). Civet RUFs described habitat utilization processes driving nocturnal movements, which may differ from those driving other core behaviors such as diurnal rest or reproductive den site selection. Finally, the spatial extent of this study was limited to the Kinabatangan Floodplain, which underwent large-scale conversion to oil palm agriculture more than 30 years ago; civet home ranges and patterns of habitat use may not be consistent within pristine forests or in regions actively being converted to oil palm agriculture. Although the extensive degradation of the region embodies the future of many lowland ecosystems, the mechanisms driving civet persistence may be modulated by the time since agricultural conversion (Gibson et al. 2013).
Future research determining the persistence of this species within mosaic landscapes should seek to scale up patterns of individual movement strategies into long-term population viability assessments. Although the civets collared in this study were considered healthy by visual inspection, animals utilizing plantations may suffer from nutrient deficiencies, immunosuppression, or other sub-lethal physiological manifestations of poor health (Ellis et al. 2012). Genetic evaluation of civet population structure would provide more detailed insights into the dispersal patterns and broader landscape connectivity of the species within modified mosaic landscapes. Based on our results, it is unknown if individuals can disperse through or establish home ranges completely contained within oil palm plantations; indeed, the maximum distance a civet was recorded within a plantation was $980 \mathrm{~m}$ from a natural forest edge. Research by Brunke et al. (2019) quantified the genetic consequences of fragmentation in the Kinabatangan for small mammals; similar analyses of the civet population would generate minimum functional patch size and connectivity thresholds to even better inform landscape planning strategies.

Given the increasing scale and extent of land use change worldwide, there is an urgent need for effective planning in and around human-modified landscapes to mitigate biodiversity losses. Although the cessation of land conversion and expansion of protected areas are undeniably crucial to stabilizing biodiversity populations (Gibson et al. 2011), the conservation value of agriculturally degraded landscapes such as the Lower Kinabatangan Floodplain should not be overlooked. By evaluating the behaviors of a generalist carnivore within such a mosaic, we began to elucidate the patterns and possible price of biodiversity persistence. To adequately conserve carnivores, the protection status of the Lower Kinabatangan must be maintained, and efforts to expand the protected area network cultivated and enacted. Simultaneously, strategies to safely facilitate civet presence within plantations should be undertaken (e.g. Ashraf et al. 2018), as oil palm may pose an ecological trap to these behaviorally adaptive carnivores (Robertson and Blumstein 2019). The execution of such recommendations will provide benefits for other lowland wildlife species while simultaneously safeguarding critical ecosystem-level processes and functions. 
Acknowledgements This project was funded by Houston Zoo, the Sime Darby Foundation, Ocean Park Conservation Foundation Hong Kong, and Phoenix Zoo. We thank the Sabah Biodiversity Centre and the Sabah Wildlife Department for supporting this research. A heartfelt thank you is extended to L. Evans, D. Stark, M. Kunde, and the staff, students, and volunteers of Danau Girang Field Centre. We are grateful for the veterinarian support provided by Drs. D. Ramírez, M. Gonzalez, L. Benedict, and P. Nagalingam. The Global Airborne Observatory is made possible by support provided by private foundations, visionary individuals, and Arizona State University.

Open Access This article is licensed under a Creative Commons Attribution 4.0 International License, which permits use, sharing, adaptation, distribution and reproduction in any medium or format, as long as you give appropriate credit to the original author(s) and the source, provide a link to the Creative Commons licence, and indicate if changes were made. The images or other third party material in this article are included in the article's Creative Commons licence, unless indicated otherwise in a credit line to the material. If material is not included in the article's Creative Commons licence and your intended use is not permitted by statutory regulation or exceeds the permitted use, you will need to obtain permission directly from the copyright holder. To view a copy of this licence, visit http://creativecommons.org/licenses/by/4.0/.

\section{References}

Abram NK, Xofix P, Tzanopoulos J, MacMillan DC, Ancrenaz M, Chung R, Peter L, Ong R, Lackman I, Goossens B, Ambu L, Knight AT (2014) Synergies for improving oil palm production and forest conservation in floodplain landscapes. PLoS ONE 9:e95388

Andersen GE, Johnson CN, Barmuta LA, Jones ME (2017) Use of anthropogenic linear features by two medium-sized carnivores in reserved and agricultural landscapes. Sci Rep 7:1-11

Aronsson M, Low M, Lopez-Bao JV, Persson J, Odden J, Linnell JDC, Andrén H (2016) Intensity of space use reveals conditional sex-specific effects of prey and conspecific density on home range size. Ecol Evol 6:2957-2967

Ashraf M, Zulkifli R, Sanusi R, Tohiran KA, Terhem R, Moslim R, Norhisham AR, Ashton-Butt A, Azhar B (2018) Alleycropping system can boost arthropod biodiversity and ecosystem functions in oil palm plantations. Agric Ecosyst Environ 260:19-26

Asner G, Martin RE, Knapp DE, Tupayachi R, Anderson CB, Sinca F, Vaughn NR, Llactayo W (2017) Airborne laserguided imaging spectroscopy to map forest trait diversity and guide conservation. Science 355:385-389

Asner GP, Knapp DE, Boardman J, Green RO, KennedyBowdoin T, Eastwood M, Martin RE, Anderson C, Field CB (2012) Carnegie Airborne Observatory-2: increasing science data dimensionality via high-fidelity multi-sensor fusion. Remote Sens Environ 124:454-465
Asner GP, Brodrick PG, Philipson C, Vaughn NR, Martin RE, Knapp DE, Heckler J, Evans LJ, Jucker T, Goossens B, Stark DJ, Reynolds G, Ong R, Renneboog N, Kugan F, Coomes DA (2018) Mapped aboveground carbon stocks to advance forest conservation and recovery in Malaysian Borneo. Biol Conserv 217:289-310

Azhar B, Lindenmayer D, Wood J, Fischer J, Manning A, McElhinny C, Zakaria M (2013) Contribution of illegal hunting, culling of pest species, road accidents and feral dogs to biodiversity loss in established oil-palm landscapes. Wildl Res 40:1-9

Bengsen AJ, Algar D, Ballard G, Buckmaster T, Comer S, Fleming PJS, Friend JA, Johnston M, McGregor H, Moseby K, Zewe F (2016) Feral cat home-range size varies predictably with landscape productivity and population density. J Zool 298:112-120

Benhamou S (2004) How to reliably estimate the tortuosity of an animal's path: straightness, sinuosity, or fractal dimension? J Theor Biol 229:209-220

Benhamou S (2011) Dynamic approach to space and habitat use based on biased random bridges. PLoS ONE 6:e14592

Benhamou S, Cornélis D (2010) Incorporating movement behavior and barriers to improve kernel home range space use estimates. J Wildl Manage 74:1353-1360

Bergen KM, Goetz SJ, Dubayah RO, Henebry GM, Hunsaker CT, Imhoff ML, Nelson RF, Parker GG, Radeloff VC (2009) Remote sensing of vegetation 3-D structure for biodiversity and habitat: Review and implications for lidar and radar spaceborne missions. J Geophys Res Biogeosci 114:G00E06

Blitzer EJ, Dormann CF, Holzschuh A, Klein A-M, Rand TA, Tscharntke T (2012) Spillover of functionally important organisms between managed and natural habitats. Agric Ecosyst Environ 146:34-43

Börger L, Franconi N, De Michele G, Gantz A, Meschi F, Manica A, Lovari S, Coulson T (2006) Effects of sampling regime on the mean and variance of home range size estimates. J Anim Ecol 75:1393-1405

Bouyer Y, Gervasi V, Poncin P, Beudels-Jamar RC, Odden J, Linnell JDC (2014) Tolerance to anthropogenic disturbance by a large carnivore: the case of Eurasian lynx in south-eastern Norway. Anim Conserv 18:271-278

Brodrick PG, Evans LJ, Martin RE, Chadwick KD, Vaughn NR, Heckler JW, Knapp DE, Asner GP (in review) Strategic conservation: integrated forest carbon and biodiversity protection. In review: Sci Adv

Brunke J, Radespiel U, Russo IR, Bruford MW, Goossens B (2019) Messing about on the river: the role of geographic barriers in shaping the genetic structure of Bornean small mammals in a fragmented landscape. Conserv Genet 20:691-704

Calenge C (2006) The package adehabitat for the R software: a tool for the analysis of space and habitat use by animals. Ecol Model 197:516-519

Chetkiewicz CLB, Boyce MS (2009) Use of resource selection functions to identify conservation corridors. J Appl Ecol 46:1036-1047

Colón CP, Sugau JB (2012) Notes on the diet of the Malay Civet (Viverra tangalunga) and other civets in logged and unlogged lowland dipterocarp rain forests in Sabah, Borneo. Malay Nat J 64:69-74 
Crooks KR, Burdett CL, Theobald DM, Rondinini C, Boitani L (2011) Global patterns of fragmentation and connectivity of mammalian carnivore habitat. Phil Trans R Soc B Biol Sci 366:2642-2651

Davies AB, Asner GP (2014) Advances in animal ecology from 3D-LiDAR ecosystem mapping. Trends Ecol Evol 29:681-691

Davies AB, Ancrenaz M, Oram F, Asner GP (2017) Canopy structure drives orangutan habitat selection in disturbed Bornean forests. Proc Natl Acad Sci 114:8307-8312

Desmet PG (2018) Using landscape fragmentation thresholds to determine ecological process targets in systematic conservation plans. Biol Conserv 221:257-260

Dislich C, Keyel AC, Salecker J, Kisel Y, Meyer KM, Auliya M, Barnes AD, Corre MD, Darras K, Faust H, Hess B, Klasen S, Knohl A, Kreft H, Meijide A, Nurdiansyah F, Otten F, Pe'er G, Steinebach S, Tarigan S, Tölle MH, Tscharntke T, Wiegand K (2017) A review of the ecosystem functions in oil palm plantations, using forests as a reference system. Biol Rev 92:1539-1569

Dobrovolski R, Loyola RD, Guilhaumon F, Gouveia SF, DinizFilho JAF (2013) Global agricultural expansion and carnivore conservation biogeography. Biol Conserv 165:162-170

Duckworth JW, Mathai J, Wilting A, Holden J, Hearn A, Ross J (2016) Viverra tangalunga. The IUCN Red List of Threatened Species, Cambridge

Ellis EC, Ramankutty N (2008) Putting people in the map: anthropogenic biomes of the world. Front Ecol Environ 6:439-447

Ellis RD, McWhorter TJ, Maron M (2012) Integrating landscape ecology and conservation physiology. Landsc Ecol 27:1-12

Evans MN, Guerrero-Sanchez S, Bakar MSA, Kille P, Goossens B (2016a) First known satellite collaring of a viverrid species: preliminary performance and implications of GPS tracking Malay civets (Viverra tangalunga). Ecol Res 31:475-481

Evans MN, Vickers SH, Abu-Bakar MS, Goossens B (2016b) Small carnivores of the Lower Kinabatangan Wildlife Sanctuary, Sabah, Borneo, including a new locality for the Otter Civet Cynogale bennettii. Small Carniv Conserv 54:26-38

Ferreira AS, Peres CA, Bogoni JA, Cassano CR (2018) Use of agroecosystem matrix habitats by mammalian carnivores (Carnivora): a global- scale analysis. Mamm Rev 48:312-327

Foley JA, DeFries R, Asner GP, Barford C, Bonan G, Carpenter SR, Chapin FS, Coe MT, Daily GC, Gibbs HK, Helkowski JH, Holloway T, Howard EA, Kucharik CJ, Monfreda C, Patz JA, Prentic IC, Ramankutty N, Snyder PK (2005) Global consequences of land use. Science 309:570-574

Foster WA, Snaddon JL, Turner EC, Fayle TM, Cockerill TD, Ellwood MDF, Broad GR, Chung AYC, Eggleton P, Khen CV, Yusah KM (2011) Establishing the evidence base for maintaining biodiversity and ecosystem function in the oil palm landscapes of South East Asia. Phil Trans R Soc B Biol Sci 366:3277-3291

Francis O (2017) Quantifying and understanding rapid land use change in the Lower Kinabatangan floodplains, Malaysian Borneo. MSci Dissertation, Cardiff University
Garabedian JE, Moorman CE, Nils Peterson M, Kilgo JC (2017) Use of LiDAR to define habitat thresholds for forest bird conservation. For Ecol Manag 399:24-36

Gaveau DLA, Locatelli B, Salim MA, Yaen H, Pacheco P, Sheil D (2019) Rise and fall of forest loss and industrial plantations in Borneo (2000-2017). Conserv Lett 12:e12622

Gehring TM, Swihart RK (2002) Body size, niche breadth, and ecologically scaled responses to habitat fragmentation: mammalian predators in an agricultural landscape. Biol Conserv 109:283-295

Gibson L, Lee TM, Koh LP, Brook BW, Gardner TA, Barlow J, Peres CA, Bradshaw CJA, Laurance WF, Lovejoy TE, Sodhi NS (2011) Primary forests are irreplaceable for sustaining tropical biodiversity. Nature 478:378-381

Gibson L, Lynam AJ, Bradshaw CJA, He F, Bickford DP, Woodruff DS, Bumrungsri S, Laurance WF (2013) Nearcomplete extinction of native small mammal fauna 25 years after forest fragmentation. Science 341:1508-1510

Handcock MS (2015) Estimates of the resource utilization function. http://www.csde.washington.edu/ handcock/ ruf. Accessed 15 Feb 2020

Harun S, Al-Shami SA, Dambul R, Mohamed M, Abdullah MH (2015) Water quality and aquatic insects study at the Lower Kinabatangan River catchment, Sabah: in response to weak La Niña event. Sains Malays 44:545-558

Hearn AJ, Cushman SA, Goossens B, Macdonald E, Ross J, Hunter LTB, Abram NK, Macdonald DW (2018) Evaluating scenarios of landscape change for Sunda clouded leopard connectivity in a human dominated landscape. Biol Conserv 222:232-240

Hinsley SA, Hill RA, Bellamy PE, Balzter H (2006) The application of Lidar in woodland bird ecology. Photogramm Eng Remote Sens 72:1399-1406

Holzner A, Rupper N, Swat F, Schmidt M, Weiß BM, Villa G, Mansor A, Sah SAM, Angelhardt A, Kühl H, Widdig A (2019) Macaques can contribute to greener practices in oil palm plantations when used as biological pest control. Curr Biol 29:R1055-R1069

Hooten MB, Hanks EM, Johnson DS, Alldredge MW (2013) Reconciling resource utilization and resource selection functions. J Anim Ecol 82:1146-1154

Jennings AP, Zubaid A, Veron G (2010) Ranging behaviour, activity, habitat use, and morphology of the Malay civet (Viverra tangalunga) on Peninsular Malaysia and comparison with studies on Borneo and Sulawesi. Mamm Biol 75:437-446

Jennings AP, Naim M, Advento AD, Aryawan AAK, Ps S, Caliman J, Verwilghen A, Veron G (2015) Diversity and occupancy of small carnivores within oil palm plantations in central Sumatra, Indonesia. Mamm Res 60:181-188

Jerosch S, Götz M, Roth M (2017) Spatial organisation of European wildcats (Felis silvestris silvestris) in an agriculturally dominated landscape in Central Europe. Mamm Biol 82:8-16

Johnson DH (1980) The comparison of usage and availability measurements for evaluating resource preference. Ecology 61:65-71

Keinath DA, Doak DF, Hodges KE, Prugh LR, Fagan W, Sekercioglu CH, Buchart SHM, Kauffman M (2017) A global analysis of traits predicting species sensitivity to habitat fragmentation. Glob Ecol Biogeogr 26:115-127 
Kertson BN, Marzluff JM (2010) Improving studies of resource selection by understanding resource use. Environ Conserv 38:18-27

Kertson BN, Spencer RD, Marzluff JM, Hepinstall-Cymerman J, Grue CE (2011) Cougar space use and movements in the wildland-urban landscape of western Washington. Ecol Appl 21:2866-2881

Lefsky MA, Cohen WB, Parker GG, Harding DJ (2002) Lidar remote sensing for ecosystem studies. Bioscience 52:19-30

Lovejoy TE, Bierregaard RO Jr, Rylands AB, Malcolm JR, Quintela CE, Harper LH, Brown KS Jr, Powell AH, Powell GVN, Schubart HOR, Hays MB (1986) Edge and other effects of isolation on Amazon forest fragments. In: Soulé ME (ed) Conservation biology: the science of scarcity and diversity. Sinauer Associates, Sunderland, pp 257-285

Martin RE, Chadwick KD, Brodrick PG, Carranza-Jimenez L, Vaughn NR, Asner GP (2018) An approach for foliar trait retrieval from airborne imaging spectroscopy of tropical forests. Remote Sens 10:199

Marzluff JM, Millspaugh JJ, Hurvitz P, Handcock MS (2004) Relating resources to a probabilistic measure of space use: forest fragments and Steller's Jays. Ecology 85:1411-1427

Mathai J, Duckworth JW, Meijaard E, Fredriksson G, Hon J, Sebastian A, Ancrenaz M, Hearn AJ, Ross J, Cheyne S, Wilting A (2016) Carnivore conservation planning on Borneo: identifying key carnivore landscapes, research priorities and conservation interventions. Raffles Bull Zool 33:186-217

McLoughlin PD, Ferguson S (2000) A hierarchical pattern of limiting factors helps explain variation in home range size. Ecoscience 7:123-130

McMorrow J, Talip MA (2001) Decline of forest area in Sabah, Malaysia: relationship to state policies, land code and land capability. Glob Environ Change 11:217-230

Melin M, Matala J, Mehtätalo L, Tiilikainen R, Tikkanen OP, Maltamo M, Pusenius J, Packalen P (2014) Moose (Alces alces) reacts to high summer temperatures by utilizing thermal shelters in boreal forests-an analysis based on airborne laser scanning of the canopy structure at moose locations. Global Change Biol 20:1115-1125

Millspaugh JJ, Nielson RM, McDonald LY, Marzluff JM, Gitzen RA, Rittenhouse CD, Hubbard MW, Sheriff SL (2006) Analysis of resource selection using utilization distributions. J Wildl Manage 70:384-395

Myers N, Mittermeier RA, Mittermeier CG, Da Fonseca GA, Kent J (2000) Biodiversity hotspots for conservation priorities. Nature 403:853

Nakabayashi M, Ahmad AH, Shiro K (2017) Horizontal habitat preference of three sympatric Paradoxurinae civet species in a small area in Sabah. Malays Borneo Eur J Wildl Res $63: 2$

Nathan R, Getz WM, Revilla E, Holyoak M, Kadmon R, Saltz D, Smouse PE (2008) A movement ecology paradigm for unifying organismal movement research. Proc Natl Acad Sci 105:19052-19059

Ordway EM, Asner GP (2020) Carbon declines along tropical forest edges correspond to heterogeneous effects on canopy structure and function. Proc Natl Acad Sci USA $117: 7863-7870$
Pardo LE, Campbell MJ, Cove MV, Edwards W, Clements GR, Laurance WF (2019) Land management strategies can increase oil palm plantation use by some terrestrial mammals in Colombia. Sci Rep 9:1-12

Pereira M, Rodríguez A (2010) Conservation value of linear woody remnants for two forest carnivores in a Mediterranean agricultural landscape. J Appl Ecol 47:611-620

Perfecto I, Vandermeer J (2008) Biodiversity conservation in tropical agroecosystems: a new conservation paradigm. Ann New York Acad 1134:173-200

Phalan B, Bertzky M, Butchart SH, Donald PF, Scharlemann JP, Stattersfield AJ, Balmford A (2013) Crop expansion and conservation priorities in tropical countries. PLOS ONE 8:e51759

Pirker J, Mosnier A, Kraxner F, Havlík P, Obersteiner M (2016) What are the limits to oil palm expansion? Glob Environ Change 40:73-81

Rembold K, Mangopo H, Tjitrosoedirdjo SS, Kreft H (2017) Plant diversity, forest dependency, and alien plant invasions in tropical agricultural landscapes. Biol Conserv 213:234-242

Ripple WJ, Estes JA, Beschta RL, Wilmers CC, Ritchie EG, Hebblewhite M, Berger J, Elmhagen B, Letnic M, Nelson MP, Schmitz OJ, Smith DW, Wallach AD, Wirsing AJ (2014) Status and ecological effects of the world's largest carnivores. Science 343:1241484

Robertson BA, Blumstein DT (2019) How to disarm an evolutionary trap. Conserv Sci Pract 1:e116

Ross J, Hearn AJ, Macdonald DW (2017) The Bornean carnivore community: lessons from a little-known guild. In: Macdonald DW, Newman C, Harrington LA (eds) Biology and conservation of musteloids. Oxford University Press, Oxford, pp 326-339

Ryall KL, Fahrig L (2006) Response of predators to loss and fragmentation of prey habitat: a review of theory. Ecology 87:1086-1093

Sálek M, Kreisinger J, Sedláček F, Albrecht T (2010) Do prey densities determine preferences of mammalian predators for habitat edges in an agricultural landscape? Landsc Urban Plan 98:86-91

Salim H, Noor HM, Hamid NH, Omar D, Kasim A, Abidin CM (2014) Secondary poisoning of captive barn owls, Tyto alba javanica, through feeding with rats poisoned with chlorophacinone and bromadiolone. J Oil Palm Res 26:62-72

Santos MJ, Rosalino LM, Santos-Reis M, Ustin SL (2016) Testing remotely-sensed predictors of meso-carnivore habitat use in Mediterranean ecosystems. Landsc Ecol 31:1763-1780

Sappington J, Longshore KM, Thompson DB (2007) Quantifying landscape ruggedness for animal habitat analysis: a case study using bighorn sheep in the Mojave Desert. J Wildl Manage 71:1419-1426

Schipper J, Chanson JS, Chiozza F, Cox NA, Hoffmann M, Katariya V, Lamoreux J, Rodrigues ASL, Stuart SN, Temple HJ, Baillie J, Boitani L, Lacher TE Jr, Mittermeier RA, Smith AT, Absolon D, Aguiar JM, Amori G, Bakkour $\mathrm{N}$, Baldi R, Berridge RJ, Bielby J, Black PA, Blanc JJ, Brooks TM, Burton JA, Butynski TM, Catullo G, Chapman R, Cokeliss Z, Collen B, Conroy J, Cooke JG, da Fonseca GAB, Derocher AE, Dublin HT, Duckworth JW, Emmons 
L, Emslie RH, Festa-Bianchet M, Foster M, Foster S, Garshelis DL, Gates C, Gimenez-Dixon M, Gonzalez S, Gonzalez-Maya JF, Good TC, Hammerson G, Hammond PS, Happold D, Happold M, Hare J, Harris RB, Hawkins CE, Haywood M, Heaney LR, Hedges S, Helgen KM, Hilton-Taylor C, Hussain SA, Ishii N, Jefferson TA, Jenkins RKB, Johnston CH, Keith M, Kingdon J, Knox DH, Kovacs KM, Langhammer P, Leus K, Lewison R, Lichtenstein G, Lowry LF, Macavoy Z, Mace GM, Mallon DP, Masi M, McKnight MW, Medellín RA, Medici P, Mills G, Moehlman PD, Molur S, Mora A, Nowell K, Oates JF, Olech W, Oliver WRL, Oprea M, Patterson BD, Perrin WF, Poliodoro BA, Pollock C, Powel A, Protas Y, Racey P, Ragle J, Ramani P, Rathbun G, Reeves RR, Reilly SB, Reynolds JE III, Rondinini C, Rosell-Ambal RG, Rulli M, Rylands AB, Savini S, Schank CJ, Sechrest W, Self-Sullivan C, Shoemaker A, Sillero-Zubiri C, De Silva N, Smith DE, Srinivasulu C, Stephenson PJ, van Strien N, Talukdar BK, Taylor BL, Timmins R, Tirira DG, Tognelli MF, Tsytsulina K, Veiga LM, Vié J, Williamson EA, Wyatt SA, Xie Y, Young BE (2008) The status of the world's land and marine mammals: diversity, threat, and knowledge. Science 322:225-230

Sikes RS, Animal Care and Use Committee of the American Society of Mammalogists (2016) 2016 Guidelines of the American Society of Mammalogists for the use of wild mammals in research and education. $\mathbf{J}$ Mammal 97:663-688

Simpson EH (1949) Measurement of diversity. Nature 163:688 Sodhi NS, Koh LP, Clements R, Wanger TC, Hill JK, Hamer KC, Clough Y, Tscharntke T, Posa MRC, Lee TM (2010) Conserving Southeast Asian forest biodiversity in humanmodified landscapes. Biol Conserv 143:2375-2384

Suraci JP, Frank LG, Oriol-Cotterill A, Ekwanga S, Williams TM, Wilmers CC (2019) Behavior-specific habitat selection by African lions may promote their persistence in a human-dominated landscape. Ecology 100:e02644
Tews J, Brose U, Grimm V, Tielbörger K, Wichmann MC, Schwager M, Jeltsch F (2004) Animal species diversity driven by habitat heterogeneity/diversity: the importance of keystone structures. J Biogeogr 31:79-92

Tilman D, Fargione J, Wolff B, D'Antonio C, Dobson A, Howarth R, Schindler D, Schlesinger WH, Simberloff D, Swackhamer D (2001) Forecasting agriculturally driven global environmental change. Science 292:281-284

van Moorter B, Rolandsen CM, Basille M, Gaillard JM (2016) Movement is the glue connecting home ranges and habitat selection. J Anim Ecol 85:21-31

Walton Z, Samelius G, Odden M, Willebrand T (2017) Variation in home range size of red foxes Vulpes vulpes along a gradient of productivity and human landscape alteration. PLoS ONE 12:e0175291

Wearn OR, Rowcliffe JM, Carbone C, Pfeifer M, Bernard H, Ewers RM (2017) Mammalian species abundance across a gradient of tropical land-use intensity: a hierarchical multispecies modelling approach. Biol Conserv 212:162-171

Wintle BA, Kujala H, Whitehead A, Cameron A, Veloz S, Kukkala A, Moilanen A, Gordon A, Lentini PE, Cadenhead NC, Bekessy SA (2019) Global synthesis of conservation studies reveals the importance of small habitat patches for biodiversity. Proc Natl Acad Sci USA 116:909-914

Yue S, Brodie JF, Zipkin EF, Bernard H (2015) Oil palm plantations fail to support mammal diversity. Ecol Appl 25:2285-2292

Zhao F, Sweitzer RA, Guo Q, Kelly M (2012) Characterizing habitats associated with fisher den structures in the Southern Sierra Nevada, California using discrete return lidar. For Ecol Manag 280:112-119

Publisher's Note Springer Nature remains neutral with regard to jurisdictional claims in published maps and institutional affiliations. 